Studia Slavica Savariensia 2016. 1-2. 386-396

DOI: $10.17668 /$ SSS.2016.1-2.386

\author{
Dubravka Smajić \\ (Osijek, Hrvatska)
}

\title{
MIRKO DIVKOVIĆ - RAVNATELJ ZAGREBAČKE GIMNAZIJE I HRVATSKI GRAMATIČAR NA PRIJELOMU HRVATSKE JEZIČNE NORME
}

\begin{abstract}
Croatian grammarian, lexicographer and translator Mirko Divković lived and worked at the turn of the $19^{\text {th }}$ to $20^{\text {th }}$ century. He started as a teacher in a grammar school and later worked as a head teacher of Classic grammar school in Zagreb for 26 years. He devoted all his creative efforts to a school, in other words he served in a school. He was the author of numerous textbooks and handbooks. He edited around 30 Croatian readers and Latin workbooks for grammar school. Truly valuable is his work on Latin-Croatian dictionary (1900) which was used throughout the whole $20^{\text {th }}$ century. He translated from Russian, mainly Tolstoj and Turgenjev and Russian folktales. The paper also presents Divković's grammatical contribution to Croatian linguistics.
\end{abstract}

Keywords: Mirko Divković, Zagreb grammar school, Croatian grammarians, lexicographers and translators, Croatian language at the turn of the $19^{\text {th }}$ to $20^{\text {th }}$ century

Mirko Divković hrvatski je slovničar, leksikograf i prevoditelj. Rođen je u Zagrebu 24. lipnja 1843. godine, a preminuo je 12. siječnja 1924. u Samoboru u 81. godini života. Kao dvadesetogodišnji svršeni zagrebački gimnazijalac upisuje studij klasične i slavenske filologije na bečkom sveučilištu, koji završava 1867. godine. U Beču se upoznaje s hrvatskim intelektualcima koji će kasnije postati prvaci hrvatskoga kulturnoga naraštaja što se okupio oko političkih ideja Strossmayera i Račkoga. Iste godine, vrativši se u domovinu zapošljava se kao gimnazijski učitelj u Varaždinu, a sljedeće godine kao namjesni učitelj u Klasičnoj gimnaziji u Zagrebu.

Međutim, već je 1870. otpušten jer kada je ban Rauch udaljio iz službe Vatroslava Jagića i Vasu Bratelja zbog "odlučna stava u političkoj aferi protujelačićevskog istupa (namjesnoga učitelja) D(avida) Starčevića", ${ }^{1}$ Mirko se Divković s još četvoricom kolega solidarizirao s nepravedno kažnjenom

1 Navodi se u Hrvatskom biografskom leksikonu, knjiga 3, Leksikografski zavod "Miroslav Krleža" 1993., Zagreb, str. 406. 
spomenutom dvojicom profesora. Uslijedio je otpust sedmorice jugoslavenski usmjerenih i tada omiljenih i sposobnih zagrebačkih gimnazijskih profesora, što je izazvalo prosvjed više od 120 đaka i dvodnevni bojkot nastave. Divković je tada imao tek 27 godina. Nakon te poznate afere, šk. g. 1870./71. našavši utočište u Rijeci, postaje učiteljem hrvatskoga jezika u riječkoj Pomorskoj akademiji, a nakon pada s vlasti bana Raucha vraća se krajem 1871. ponovno u zagrebačku Klasičnu gimnaziju, koju će pak od 1882. do umirovljenja 1908. voditi kao ravnatelj - dakle punih 26 godina. Kada se 1895 . Klasična gimnazija podijelila na donjogradsku i gornjogradsku, ravnateljevao je gornjogradskom. Gornjogradska gimnazija kao prva zagrebačka gimnazija bila je osnovana još davne 1607. godine i smještena na Trgu Katarine Zrinske. Osnovali su je isusovci u napuštenom dominikanskom samostanu. Nastavni je jezik dugo bio latinski, a 1842. godine u njoj se počinje učiti hrvatski jezik.

Nazivajući počasno umirovljenoga ravnatelja Divkovića ,zaslužnim veteranom našega školstva“, o njegovu osamdesetom rođendanu, prijatelj Stjepan Bosanac u Nastavnom vjesniku ovako piše: „Mirko Divković svakako je jedan od najmarkantnijih zastupnika naše srednje škole (...) vrijedan velikoga štovanja i toplih simpatija." (BOSANAC 1924: 6-7) Ističe savjesnost, ali i umješnost kojom je Divković vodio zagrebačku gimnaziju, i to za vladavine bana Khuena. Bosanac ovo pripovijeda o njemu u tim politički teškim vremenima: "U jednoj gimnaziji zagrebačkoj rastao je od godine do godine broj đaka, te je najzad pred osnutkom druge gimnazije u donjem gradu narastao mislim do pune tisuće. Svu tu mladež držati u redu, da vatrena i domoljubna za omražene vlade Khuenove ne nastrada, pogotovu kada se Khuen običavao često šetati Strosmajerovim šetalištem ispred gimnazijske zgrade prepune đacima kao košnica pčelama, za to se htjelo ne samo mnogo takta i odrešitosti nego još više pravoga auktoriteta, koji je Divković u punoj mjeri svagda uživao kod mladeži.“ (BOSANAC 1924: 7) U naglašeno pozitivnom svjetlu oslikava ga i Josip Pasarić u nekrologu iz 1924. godine nazivajući ga „nestorom hrvatskih srednjoškolskih profesora, velikim učiteljem i nezaboravnim uzgajateljem nepreglednoga niza hrvatskih inteligenata“". (BOSANAC 1924: 161) I ne samo njih nego je „,iz Divkovićeva učiteljskoga zbora izašla čitava plejada hrvatskih književnika i sveučilišnih profesora, o čemu nam uz ostala svjedoče ova imena: Arnold, Badalić, Bazala, Boranić, Bosanac, Broz, Dukat, Florschütz, Golik, Gudel, Hondl, Ivšić, Klaić, Körbler, Livadić, Musić, Pavletić, Radić Ante, Šenoa Milan, Šrepel, Šurmin.“ (BOSANAC 1924: 164)

No Divković nije bio samo profesorom i gimnazijskim ravnateljam nego je skrbio i o hrvatskoj knjizi i kulturnom prosvjećivanju. Tako se posebno vrijednom ističe i Divkovićeva odgovorna uloga tajnika od 1871. godine u Matici ilirskoj u vrijeme njezina preporoda i preobrazbe. Za svoga tajnikovanja napisao je prvu kratku povijest Matice od njezina osnutka 1842. godine do 1874., kada je zaživjela preustrojena kao Matica hrvatska. Josip Pasarić ističe kako se „ta povijest kao tajnički izvještaj čitala na glavnoj skupštini od 29. 
studenoga 1874., kojega je dana u život stupila preustrojena Matica Hrvatska s novim predsjednikom Ivanom Kukuljevićem i novim tajnikom Tadijom Smičiklasom.“ (BOSANAC 1924: 163) Taj je Divkovićev kratki pregled Matičine povijesti tiskan u programu zagrebačke gimnazije (1874.-75.) i kasnije je poslužio kao polazište Smičiklasovoj opširnoj obradi u Spomen-knjizi Matice hrvatske.

Za njegova tajnikovanja Matica je započela izdavati i nagrađivati popularna poučna djela, izdala je neka od Šenoinih i Vrazovih ukoričenja te počela širiti Matičine knjige među školskom mladeži po Hrvatskoj, Slavoniji i Dalmaciji. Pasarić zaključno ocjenjuje da je u Matici u vrijeme Divkovića kao tajnika postavljena čvrsta osnova njezinu kasnijemu uspjehu i napretku.

Divković je ipak svoj najveći stvaralački napor usmjerio na školu, tako reći služio je srednjoj školi, stoga se dao i na pisanje srednjoškolskih, udžbeničkih priručnika priredivši tridesetak izdanja hrvatskih čitanaka za I., III. i IV. razred gimnazije i latinskih vježbi za prva dva gimnazijska razreda.

Bavio se i prevoditeljstvom. Prevodio je s ruskoga, najviše Tolstojevu i Turgenjevljevu prozu, a 1923. godine objelodanio je i Ruske narodne pripovijetke.

Posebno je vrijedan njegov leksikografski rad, isprva na Rječniku hrvatskolatinskom (1877.), a potom na izradbi Latinsko-hrvatskoga rječnika (1900.). Na prvom izdanju Latinsko-hrvatskoga rječnika iz 1881. radio je kao suradnik Sebastijana Žepića, a drugo je izdanje sam priredio 1900. godine. Taj je njegov rječnik ostao u uporabi i do današnjih dana i možemo ga i sada vidjeti na mnogim policama naših knjižnica.

Poznato je da je Divković u Samoboru kao umirovljenik izradio i Rječnik hrvatskoga jezika. S. Bosanac navodi: "Tako je po nagovoru prijateljâ sastavio rječnik hrvatskoga jezika kao manje izdanje Broz-Ivekovićeva rječnika. Rukopis je gotov, pa bi samo trebalo naći nakladnika, koji će to potrebno djelo štampati, jer je Broz-Ivekovićev veliki rječnik već posve rasprodan, a rječnik se traži." (BOSANAC 1924: 5) Međutim, ostavši samo u rukopisu, rječnik je danas na žalost zagubljen.

Osim latinskoga, poučavao je i proučavao hrvatski jezik, pa tako među njegovim školskim priručnicima posebno važno mjesto zauzimaju u više navrata mijenjane i dopunjavane, odnosno poboljšavane i usavršavane hrvatske gramatike. Godine 1879. pojavio se njihov prvi dio tako i naslovljen Hrvatske gramatike I. dio. Oblici, a 1881. godine drugi dio pod naslovom Hrvatske gramatike II. dio. Sintaksa. Od 1898. godine Divković oba dijela tiska zajedno - objedinjena, i to pod nazivom Oblici i sintaksa hrvatskoga jezika. Ta je gramatika, tako objedinjena, na koncu doživjela ukupno dvanaest izdanja, posljednje je objelodanjeno 1917 . godine, ${ }^{2}$ pa se u dijelu literature ističe da se

${ }^{2}$ Z. Vince (1986: 416) pogrješno navodi da je Divkovićeva gramatika doživjela jedanaest izdanja. Točno je da je posljednje izdanje, kako i Vince navodi, tiskano 1917., ali to je bilo dvanaesto prerađeno. Jedanaesto izdanje "pregledano i potpunjeno" 
do tada i zadržala u školama. Novija istraživanja S. Ham osporavaju tu tvrdnju pokazujući da su se Divkovićeve gramatike zadržale u upotrebi mnogo duže, još nekoliko desetljeća: "Bile su suvremenice i Maretiću, Rešetaru, Florschützu, Dujmušiću - iz njih se učilo sve do II. svjetskoga rata!" (HAM 2006: 136)

Važno je istaknuti još jedan vrijedan Divkovićev gramatički priručnik koji također donosi prikaz sintakse hrvatskoga književnoga jezika. Pojavljivao se dvojako naslovljen - isprva kao Nauka o izreci, od prvoga izdanja 1880. godine, a kasnije, od 1899. kao Rečenica za školu. Ta je knjiga doživjela čak trinaest izdanja, a posljednji je put objelodanjena 1917. godine.

Divković je očito bio jedan od najplodnijih gramatičara u Hrvata. ${ }^{3}$

Spomenuti Divkovićevi gramatički priručnici mijenjajući svoju kakvoću i obujam, u brojnim novim izdanjima mijenjali su i svoje naslove. Divković je zapravo napisao tri gramatike: najprije oblike, a potom sintaksu rečenice te na kraju sintaksu oblika. Svaka od tih triju knjiga tiskana je barem pod dvama naslovima: Hrvatske gramatike I. dio. Oblici i Oblici hrvatskoga jezika za srednje škole, dok su sintakse objelodanjivane pod četirima naslovima: Hrvatske gramatike II. dio. Sintaksa za školu, Hrvatska sintaksa za školu, Nauka o izreci i Rečenica za školu. Objedinivši prve dvije gramatike u jednu knjigu, izdao ih je pod jednim, posebnim naslovom: Oblici i sintaksa hrvatskoga jezika za srednje škole.

$\mathrm{Na}$ izradu gramatike Divkovića je potaknulo treće objelodanjivanje Slovnice hrvatske znamenitoga prvaka zagrebačke filološke škole Adolfa Vebera Tkalčevića, u kojoj je bila tek ponešto ublažena, poznata Veberova čvrsto zacrtana zagrebačka jezikoslovna smjernica ("napustio je pisanje $e$, slogotvorno $r^{\prime \prime}$ ) (VINCE 2002: 628). Kako je Veberova Slovnica zapravo u biti ostala jednaka, a Skladnja mu je već ranije doživjela žestoku kritiku V. Jagića, bio je to dovoljan poticaj uz neke druge razloge da se krajem sedamdesetih godina, kao Jagićev sumišljenik, Mirko Divković prihvati pisanja hrvatske školske gramatike.

Naime, Divković će u polemici s Veberom otvoreno ustvrditi da Veberova slovnica nije dobar priručnik jer da je nakon triju godina Divkovićeva podučavanja prema toj slovnici "sva skoro muka oko hrvatskoga jezika bila

objelodanjeno je 1908., što je podatak koji se ne nalazi u Vinceovu kratkom bibliografskom popisu.

${ }^{3}$ Divković je i s pedagoškoga motrišta razmatrao pristup učenju gramatike prema tadašnjem gimnazijskom programu. U svom stručnom članku Ima li u gimnaziji preterećivanja? problematizira program učenja potpuno jednakih gramatičkih sadržaja u tadašnjoj nastavi četiriju jezika: hrvatskoga, njemačkoga, latinskoga i grčkoga. Zaključuje na konkretnim primjerima kako se jedan gramatički pojam u jezičnim udžbenicima tih jezika poučava na četiri različita načina i stoga se zalaže za jedinstvenu gramatičku terminologiju i međujezičnu korelaciju u učenju jednakih gramatičkih sadržaja (DIVKOVIĆ 1902: 483-496). 
uzaludna, da sam sebe i svoje učenike hranio neistinami, da su naše gramatike nalik matematičkoj zadaći nevaljala učenika, koji sam radi svoj zadatak, a rezultat prepiše od dobroga, tj. rezultat je istinit, a put kojim se do nj dolazi, da nije istinit" (DIVKOVIĆ 1879a: 565-566). Divković je mišljenja kako je najveća muka krivim putem do cilja doći. Ističe i da je na ispitu zrelosti opazio vrlo manjkavo učeničko znanje o oblicima, a čak i u mlađih učitelja, pa pitajući se za razlog svemu tomu, pronalazi uzrok upravo u školskoj gramatici.

Napominje da je zemaljskoj vladi već ranije predlagao da se Veberova slovnica zamijeni latinicom tiskanom Daničićevom, ${ }^{4}$ ali nije dobio povoljan odgovor. Sve ga je to, dakle, ponukalo da se lati ozbiljne zadaće i prione izradi nove, vlastite slovnice za škole, i to po uzoru najviše na Miklošiča i Daničića, kako sam u proslovu kaže: "Sintaksa ova izradjena je po Miklošićevoj 'vergleichende Syntax der slavischen Sprachen, Wien 1868.-1674.' i Daničičevoj Sintaksi, Beograd 1858. Razdioba padežâ udešena je prema latinskoj slovnici najviše za to, jer se u III. razredu uči nauka o padežih u latinskom i hrvatskom jeziku. Nauk o padežih s priedlozi izradio je kolega A. Musić najviše po Daničiću."

Veber je prve dvije Divkovićeve gramatike podvrgnuo oštroj kritici, i to $\mathrm{s}$ pravom, što je kasnije izazvalo žestoku polemiku. Rasuđujući o Oblicima, on podsjeća da priručnik namijenjen potrebama srednjega učilišta treba da "razpravlja sve slovničke pojmove i česti... Prema tomu zahtjevu, komu se prigovoriti neda, Divkovićevi su oblici veoma manjkavi, razpravljajući samo njeke slovničke pojmove i česti, a sasvim šuteći o njekih posve potrebnih." (VEBER 1887: 36) Osim nepotpunosti, protuslovlja, nesigurnosti, premalo glavnih pravila i sustava, "mnogo samovolje, koja svaki čas drugčije postupa" (VEBER 1887: 53), Veber Oblicima još zamjera što "sadržavaju mnogo toga, što u skladnju spada, ponavljaju ista pravila na više mjestah, a pisani su više dijalektički, nego li kategorički". ${ }^{6} \mathrm{~S}$ didaktičkoga motrišta Oblici također ne

\footnotetext{
${ }^{4}$ Divković je to predložio 1875. godine: "Zato sam ja već prije četiri godine predložio u konačnoj sjednici vis. kr. zem. vladi, da se Veberova slovnica zamjeni Daničićevom, latinicom štampanom, ali nedobismo odgovora. Ovo me ponuka te se odvažih na mučno djelo, za koje sam unapred znao, da će imati one protivnici, koji su već naučili jednu slovnicu, a druge im se više učiti neće..." (DIVKOVIĆ 1879a: 566)

5 Divković, Mirko, Hrvatske gramatike II. dio. Sintaksa za školu, Sveučilišna knjižara Franje Župana 1881, Zagreb, str. I. (Tiskarskom je pogrješkom u proslovu gramatike navedena godina 1674. umjesto 1874., i vergleichende umjesto Vergleichende.)

${ }^{6}$ Gdjekad Veber u kritici i podrugljivo progovara: "Pak taj djetetu nepoznani jezik (staroslavenski, D. S.) ima biti pomagalom, da se svoj jezik, koji već govori, podpuno nauči, proti nepobitnomu didaktičkomu načelu, da pomagala imaju biti bolja od same stvari, kojoj pomažu. Doista, to znači s moždjani i tielo izpijati našoj mladeži. Još bi se mogao njekako razumjeti postupak g. pisca (M. Divkovića, D.S.), kad bi kazao: Ova rieč, ovaj nastavak ovako glasi u staroslavenskom jeziku, a ovako se je ustanovio u hrvatskom; ali on uzima, kano što mu se iz slovnice jasno razabire, da je staroslavenski
} 
zadovoljavaju školskim potrebama, smatra Veber. Jedan od osnovnih razloga tomu jest pretjerana staroslavenština, jer se autor ne drži samo hrvatske osnove, nego ju počesto miješa sa staroslavenskom što, prema Veberu, dokazuje da se Oblici bez staroslavenštine ne mogu razumjeti (VEBER 1887: 55). U toj svojoj osudi Veber Divkoviću predbacuje da povrjeđuje gimnazijski propis kojim se učitelju brani upletati povijest o starijim jezičnim oblicima u učenje suvremenih oblika hrvatskoga štokavskoga narječja.

Premda Divković postaje Veberu suparnikom u sastavljanju srednjoškolskih slovnica pa bi tko Veberu kao ocjenjivaču mogao pripisati i kakvu pristranost, mora se priznati da je Veberova kritika najvećim dijelom utemeljena. Otuda je njihov sukob potpuno razumljiv, ali i neizbježan, jer se zapravo radi o dvjema različitim jezičnim koncepcijama. S jedne je strane u Adolfa Vebera kao središnjega predstavnika zagrebačke filološke škole, pristup gramatici sinkronijski, dok je s druge strane Divkovićevo djelo obilježila dijakronija jer je zbog mladogramatičarskoga utjecaja on bio mišljenja da tadašnje trenutačno stanje u hrvatskom jeziku valja ponajprije objašnjavati staroslavenskim i(li) starim hrvatskim jezikom, odnosno na temelju jezikoslovnih stajališta Karadžića i Daničića - premda su Divkovićevi zagrebački prethodnici Antun Mažuranić i Adolfo Veber bili potpuno protivnici takva tumačenja i metode. Stoga se Mirka Divkovića kao gramatičara svrstava u jezikoslovnu struju hrvatskih vukovaca, tj. onih koji su slijedili karadžićevsko-daničićevski jezikoslovni model. Kao hrvatski vukovci, osim Divkovića, spominju se redovito Pero Budmani, Tomo Maretić, Franjo Iveković i Ivan Broz. No prava je istina to da se u svojem ranom gramatičarskom radu Divković toj struji priklanja zapravo tek deklarativno, ${ }^{7}$ odnosno tek dijelom jezične norme koju propisuje u svojim gramatikama. Veći dio normativnih jezičnih obilježja njegovih ranih gramatika potvrđuje da je izrastao na temeljima zagrebačke filološke škole, što i jest prirodno jer je to bila jedina norma kojom se i dotada služio. Bjelodano to pokazuje, primjerice, jezična norma koju je Divković primijenio u svojim prijevodima ruskih klasika objavljenima na početku 20. stoljeća, dakle nakon što je objelodanjen Hrvatski pravopis Ivana Broza (1892.) kojim se uvodi fonološko načelo u hrvatski pravopis. Iako je Divković sva svoja izdanja gramatika koja su uslijedila odmah nakon pojave Brozova

i hrvatski jedan jezik, pak iz onoga navodi rieči i nastavke, kakovih u današnjem hrvatskom jeziku neima, tako da se diete svaki čas osupnuti mora." (VEBER 1887: 36) 42)

7 O deklarativnim stavovima o zajedničkom književnom jeziku i zapravo samo deklarativnom prihvaćanju vukovskoga modela u nekih hrvatskih gramatičara govori B. Tafra (TAFRA 1993a: 363-388; TAFRA 1993b) pokazujući kako unatoč takvim deklarativnim stavovima pojedini jezikoslovci u svojim gramatikama ne napuštaju neka od osnovnih načela hrvatske gramatičke škole. Kasnije će to potvrditi i S. Ham (HAM 2006). 
pravopisa uskladio $\mathrm{s}$ novim pravopisnim načelima, ${ }^{8} \mathrm{u}$ svojem prijevodu Turgenjevljeve pripovijesti $U$ predvečerje, tiskanom 1901. (u izdanju naslovljenom Izabrane pripoviesti ${ }^{9}$ ), ne odmiče se od morfonološkoga pravopisnog načela, što se vidi iz sljedećega:

1. Divković u prijevodu redovito bilježi dvoglasnik ie za dugi odraz jata (rieka, brieg, biel, liepo, smiešio se itd.) i je za kratki odraz (čovjek, sjetiti se, djetinji, vjetrić itd.).

2. U Divkovića nema slova đ, već umjesto njega za sliveni izgovor dosljedno uporabljuje dvoslov dj (i gj): ledja, djak, mladji, nadjeno, nasladjivati se itd.

3. Divković ima oblike sladko, obćenito, naručaba, uzplamtjeti, bezposlica, razstati se, strastno, raznovrstni itd., odnosno riječi ne piše "kako se izgovaraju (...) ili po glasu (...) eufonički", već "kako su postale (...) po korjenu (...) etimologički", jer "u hrvatskom se jeziku i prvobitne, a osobito izvedene i promienjene rieči pišu etimologički po pravilih slovničkih" (VEBER 1876: 21).

Vukovska norma u navedenom Divkovićevu prijevodu ogleda se ponajprije u jednakim množinskim imeničkim nastavcima za dativ, lokativ i instrumental koji nisu tradicionalni, zagrebački, nego novi, povukovljeni (svojim očicama; na širokim usnama, u mrkim očima; među obrvama, glavama, tudjim riečima itd.). Posebno se to zapaža u odnosu na gramatičku normu u ostalim četirima Turgenjevljevim pripovijestima koje je preveo Josip Miškatović, a tiskani su u istom izdanju Izabranih pripovijesti zajedno s Divkovićevim prijevodom. Miškatović se, uz morfonološki pravopis, dosljedno služi i gramatičkom normom zagrebačke filološke škole navodeći neujednačene množinske nastavke (po žutih očicah, u kartah; kovanimi škrinjami, iskrami, za njimi, s bielimi kolonami, pred ljudmi itd.). Divković je u svojem prijevodu zadržao glagolski pridjev sadašnji u atributnoj ulozi (pužeća bubica) koji u vukovskoj gramatičkoj normi ne postoji kao zasebna sklonjiva vrsta participa.

Veberovo je gramatičko nazivlje tradicijsko, zagrebačko, kakvo i zahtijeva tadašnji gimnazijski propis, a Divkovićevo u Oblicima djelomice drukčije, da bi se gotovo sa svakim novim izdanjem te gramatike sve više približavalo vukovskom. Divković je primjerice bez potrebe prema Karadžiću zamijenio "ono što zapadni narodi zovu cirkumfleks, a mi Hrvati zavinuti naglasak"

\footnotetext{
${ }^{8}$ Najprije svoje 5. izdanje Nauke o izreci 1892., potom 3. izdanje Hrvatske sintakse za školu 1893. i na koncu 4. izdanje Oblika hrvatskoga jezika 1894. godine. Dakako, usklađena su s novim, fonološkim pravopisom i sva sljedeća izdanja tih gramatika.

${ }^{9}$ Riječ je o zbirci proze Ivana S. Turgenjeva Izabrane pripoviesti u prijevodu Josipa Miškatovića i Mirka Divkovića (Naklada Matice hrvatske, Zagreb, 1901.).

${ }^{10}$ Ako bi se navedenu primjenu morfonološkoga pravopisa moglo objasniti značajno ranije nastalim Divkovićevim prijevodom u odnosu na vrijeme tiskanja knjige, odnosno nastankom toga prijevoda prije izlaska Brozova pravopisa, ipak je teško prihvatiti pomisao da je Divkovićev prijevod čekao čak više od devet godina na objavljivanje.
} 
(VEBER 1887: 36-37) tzv. oštrim iako, kako Veber kaže, propisana slovnica za učilišta ima obratno.

Sve je to bilo uzrokom žestokoj međusobnoj polemici, u koju će se kasnije uključiti i Tomo Maretić. Divkovićeva je Sintaksa od Veberova kritičarskoga pera doživjela sličnu razložnu oštru kritiku kao i Oblici.

Iako se Divković ubraja među najplodnije hrvatske slovničare - zna se da postoji ukupno 29 izdanja njegovih slovnica - zapaža se da ne ide u red boljih, napose ne svojim ranim gramatikama, što se dobrim dijelom razabire osim iz spomenutih Veberovih kritika, kasnije i iz Maretićevih.

Divkovićevi su suvremenici, dakle, podosta kudili njegov slovničarski rad ocjenjujući kako su mu rane gramatike dobre tek u onim dijelovima koji su prepisani iz Daničićeve ili Miklošičeve gramatike, a sam autor ocijenjen je nepouzdanim gramatičarem. To su mišljenje zastupali A. Pavić i I. Milčetić. Uz spomenutu Veberovu oštru kritiku, u literaturi se obično ističe sud Armina Pavića, sveučilišnoga profesora kojega je vlada zadužila za prosudbu Divkovićeve gramatike. Prema njegovoj ocjeni Divkovićeva školska gramatika uopće nije za škole jer vrvi brojnim pogrješnostima ${ }^{11}$ te da "u toj knjižici gotovo ni jedno pravilo nije istinito, ili da bar nije potpuno, ili da bar nije jasno izrečeno". ${ }^{12}$

Povjesničar jezika Zlatko Vince sažeo je zamjerke iznesene na račun Divkovićeve gramatike ovako: "Prigovaralo se Divkoviću da je tek prepisivao Miklošiča, ali da ga nije uvijek dobro razumio, pa se čak nije oslobodio ni složenog Miklošičeva izražavanja, nepodobna za učenike." (VINCE 1986: 412)

U polemikama o Divkovićevim gramatikama u prvi mah pretegnulo je Veberovo motrište, osnaženo mišljenjem A. Pavića. Međutim, Divkovićeva uporna obrana potpomognuta je Daničićevim, Valjavčevim i Živanovićevim svjedočenjem ${ }^{13}$ da su mu gramatike dobre, što je u konačnici odnijelo prevagu. $\mathrm{Pa}$ iako je Veber razložno upozoravao na probleme koje će izazvati vladina odluka da se za prve razrede gimnazije "pušta (...) učiteljskim sborovom na volju, da Divkovićevu (gramatiku, napomena D.S.) uvedu ili neuvedu, dodavši razlog, jer da uz izdašnu pripomoć vješta učitelja može dobro služiti, a pogrješke da će Divković u II. izdanju popraviti", (VEBER 1887: 86) ne samo

11 Taj je negativan sud istaknuo i Veber u zaključku svoje polemike $N a$ razstanak $g$. Divkoviću: "Ob Oblicih Divkovićevih izrekao je i sveučilišni profesor, Armin Pavić, koji je i na gimnaziji služio i koji se ex professo bavi slavenskom filologijom, visokoj vladi svoj sud, da ta knjiga radi mnogih pogrješakah, nepodpunosti i nejasnoće nije za škole." (VEBER 1887: 86)

${ }^{12}$ Narodne novine, 1879., br. 243. (prema VINCE 1986: 412)

13 "Divković (se) pozivao na Daničićevo, Valjavčevo i Živanovićevo mišljenje koje je bilo pozitivno." (VINCE 2002: 628.) U predgovoru svoje prve gramatike Divković navodi ovu zahvalu: "Napokon mi se je osobito zahvaliti gosp. prof. Gj. Daničiću i gosp. prof. M. Valjavcu na trudu, kojim su knjižicu ovu pregledali i ocienili." (Divković, Mirko, Hrvatske gramatike I. dio. Oblici, Dionička tiskara 1879b, Zagreb, str. I) 
da su Divkovićeve knjige odobrene za školu već su postupno sasvim zamijenile Veberove. ${ }^{14}$

Kako je ovdje već upozoreno, u pitanju su bile dvije različite jezične koncepcije i u cjelini gledano riječ je ipak "o gramatikama dvaju jezičnih i pravopisnih tipova istoga jezika" (JONKE 1956: 68), stoga Veber predviđa nedaće koje čekaju i učitelje, a i učenike: "Ali uzmimo, da sve gimnazije prihvate Divkovićeve oblike, najprije se na njih neće moći učiti, kako se imadu hrvatske rieči izgovarati, pisati i tvoriti, jer toga u onih Oblicih neima dielom ništa, dielom vrlo malo, a to su ipak prve potrebe. Zatim će se dogoditi, što obično biva, da jedan ter isti učitelj predaje i u I. i u II. razredu oblike, pak će to ljetos barem morat učiniti povodom dvijuh različitih slovnicah, što mora $\mathrm{i}$ vještijega učitelja zbuniti (...) Ali recimo i to, da će učitelj kako tako svladati tu težkoću, kako će ju svladati učenici, koji će se u III. razredu morati, pošto Divkovićeve neima, po Veberovoj učiti skladnju, koja u uzkom savezu stoji s oblikoslovjem? Tu jih mora zabuniti većim dielom druga terminologija, druge oznake poznanih jur pojmovah i mnogo poznanim protivnih mnijenjah (...) Tu metežu neima ni kraja ni konca!" (VEBER 1887: 87-88)

Međutim, Divkovićeva je gramatika dobila pozitivnu ocjenu Tome Maretića, no autor te ocjene javno je isticao "da mu je Divkovićeva sintaksa već i zato mila, što će iztisnuti"(VEBER 1887: 456) Veberovu. Dakle, Maretić zapravo nije hvalio Divkovićev rad iz znanstvenih pobuda, o čemu sažeto svjedoči Veberova poruga o polemičkom Poručku Maretiću: "Po njem je (Maretiću, napomena D.S.) Divković gotovo sva tumačenja izveo po Miklošiću ili po Daničiću, dakle skoro ništa sam po sebi; u njegovoj sintaksi ima i toga, što nebi trebalo pisati, a ima i toga što bi nuždno trebalo metnuti; on nije svega tako točno kazao, da bi ga učenik mogao razumjeti; navadja nesgodnih citatah; napokon mu pisanje nije prosto od svake pogrješke (...) Ublažuje doduše prijatelj svoj sud opazkom, da su to većinom sitne stvari, dakle su manjinom svakako krupne zaključuje Veber (VEBER 1887: 457).

Nameće se zaključak kako se pozitivnom kritikom Divkovićeve gramatike Maretić zapravo obračunavao sa svojim pravim, koncepcijskim protivnikom Veberom, jer Veber odbija biti "historičkim gramatikom, komu je predmet sve, što je postojalo i postoji u jeziku" (VEBER 1887: 454-455), već odlučuje biti "didaktičkim gramatikom, koji uči samo ono, što je u jeziku najobćenitije $i$ najpravilnije" (VEBER 1887: 454-455), i zato ne može (i ne želi) ${ }^{15}$ slijepo slijediti Daničićev i Miklošičev jezikoslovni nauk. Stoga po Maretićevu mišljenju Divkoviću je valjalo dati prednost pred Veberom jer "ako nesliediš,

\footnotetext{
${ }^{14}$ Veber umire 1889. godine, dvije godine nakon objelodanjivanja drugoga izdanja Divkovićevih Oblika.

15 "... hrvatska se slovnica mora pisati Miklošićevim načinom, jer je on u tom uzornik. Zašto da mora? Zar u načinu stoji nauka? Zar mi svi da samo prepisujemo Miklošića?" (VEBER 1887: 455)
} 
urgira očevidno pisac (Maretić, napomena D.S.), Daničićeva i Miklošićeva načina, nisi u skladu s pravom naukom", ironično Veber parafrazira Maretića.

I tako je Divkovićeva školska gramatika dobila prolaznu ocjenu - jedva, ali ju je dobila. Pomalo je potiskivala Veberovu, da bi ju na koncu vrlo ubrzo oštro napao upravo onaj koji ju je promicao i dao joj pozitivnu ocjenu - sam Tomo Maretić. Naime, Maretićeva je nakana bila da se probije zapravo njegova školska gramatika, koja je objelodanjena iste 1899. godine kada izlazi novo, osmo izdanje Divkovićevih Oblika i sintakse hrvatskoga jezika, a i osmo mu izdanje Rečenice za školu. I tako uskoro Maretić i Divković postaju pravi "takmaci u objavljivanju hrvatskih školskih gramatika"(VINCE 1986: 411).

"Tako je dakle kraj posljednjeg desetljeća 19. stoljeća u znaku oštrih polemika između dvaju autora školskih gramatika: Mirka Divkovića, gimnazijskog profesora, koji je svojim gramatikama dominirao više od dvaju desetljeća, i Tome Maretića, sveučilišnog profesora." (VINCE 1986: 412) No Divković nije bio ni izbliza gramatičar takve znanstvene snage i stručnosti kao Maretić.

Novija pak istraživanja pokazuju kako su se Divkovićeve gramatike kao školski udžbenik upotrebljavale čak pedesetak godina - "nekoliko godina uz Veberove školske slovnice; a poslije Veberove smrti 1889. umjesto Veberovih slovnica." (HAM 2006: 136) ${ }^{16}$ Povlačenju Divkovićevih gramatika iz školskih programa na koncu su presudile Maretićeve školske gramatike, koje su ih zamijenile.

\section{Zaključak}

U prosvjetnim je krugovima Mirko Divković s pedagoškoga gledišta ocijenjen kao „, jedan snažan orač na njivi hrvatske prosvjete, koji je ostavio iza sebe duboke i trajne brazde“. ${ }^{17}$ Međutim, o njegovu djelu u našoj suvremenoj literaturi pisalo se rijetko, najčešće u okviru kakva povijesnoga pregleda hrvatskoga jezikoslovlja. ${ }^{18}$ U ostalim jezikoslovnim radovima ${ }^{19}$ spominjan je obično usputno, tek da bi se izrazio suodnos $\mathrm{s}$ njegovim jezikoslovnim suvremenicima koji su ostavili snažniji trag u hrvatskoj jezikoslovnoj povijesti od Divkovićeva i između čijih su gramatičkih uradaka Divkovićeve

\footnotetext{
6 Z. Vince postavlja zanimljivo pitanje: "Kako je tako dugo vremena mogla Divkovićeva gramatika izlaziti u novim izdanjima s toliko mnogo stvarnih pogrešaka." (VINCE 1986: 415)

${ }^{17}$ Iz nekrologa koji je Mirku Divkoviću posvetio učitelj Bogumil Toni (Samoborski list, 1924.)

${ }^{18}$ Općenito o njegovu mjestu u hrvatskom jezikoslovlju na prijelazu stoljeća može se doznati iz zapisa Z. Vincea (2002.), a podrobniji osvrt na Divkovićev slovničarski rad daje samo S. Ham u svojoj Povijesti hrvatskih gramatika (2006.).

${ }^{19}$ Spominju ga u prikazu jezikoslovnih strujanja toga vremena Lj. Jonke i B. Tafra, te ponovno Z. Vince.
} 
srednjoškolske gramatike značile tek prijelaz jer su donosile "koncepcijsku novinu u hrvatskoj gramatičkoj tradiciji" (SAMARDŽIJA 2004: 140-141). U hrvatskoj je gramatičarskoj povijesti zapamćen kao ,školski i školnički gramatičar" (HAM 2006: 144) koji je u srednje škole uveo vukovsku gramatičku normu te fonološki pravopis, priklanjajući se pravopisnim rješenjima Ivana Broza.

Djelujući na prijelazu stoljeća, doživio je osobnu mijenu od gramatičara koji je pisao normom zagrebačke škole do potpunoga vukovca i tako je slijedom te svoje mijene gotovo zrcalno odslikao slijed normativne promjene koja je zahvatila hrvatski književni jezik na prijelomu 19. u 20. stoljeće.

\section{Literatura}

BOSANAC 1924 = BOSANAC S. Mirko Divković // Nastavni vjesnik, № XXXII. 1924. 5-9.

BROZ 1892 = BROZ I. Hrvatski pravopis. Zagreb, 1892.

DIVKOVIĆ $1879 \mathrm{a}=$ DIVKOVIĆ M. Odgovor na sud g. Vebera // Narodne novine, 1879. 226-235.

DIVKOVIĆ 1879b = DIVKOVIĆ M. Hrvatske gramatike I. dio. Oblici. Zagreb, 1879.

DIVKOVIĆ 1881 = DIVKOVIĆ M. Hrvatske gramatike II. dio. Sintaksa za školu. Zagreb, 1881.

DIVKOVIĆ 1902 = DIVKOVIĆ M. Ima li u gimnaziji preterećivanja? // Nastavni vjesnik, № X. 1902. 483-496.

DIVKOVIĆ 1924a = Mirko Divković 1843.-1924. // Nastavni vjesnik, № XXXII. 1924. 161-170.

DIVKOVIĆ 1924b = Mirko Divković // Samoborski list, № 2, od 15. siječnja 1924.

HAM 2006 = HAM S. Povijesni pregled hrvatskih gramatika. Zagreb, 2006.

HRVATSKI BIOGRAFSKI LEKSIKON = Hrvatski biografski leksikon, knjiga 3, Leksikografski zavod "Miroslav Krleža". Zagreb, 1993.

JONKE 1956 = JONKE Lj. Veberove zasluge za naš književni jezik // Rad JAZU, 1956. № 309. 33-80.

SAMARDŽIJA 2004 = SAMARDŽIJA M. Iz triju stoljeća hrvatskoga standardnog jezika. Zagreb, 2004.

TAFRA 1993a = TAFRA B. O hrvatskim vukovcima iz drugoga kuta // Rasprave Zavoda za hrvatski jezik, 1993a. № 19. 363-388.

TAFRA 1993b = TAFRA B. Gramatika u Hrvata i Vjekoslav Babukić. Zagreb, 1993b.

VEBER 1876 = VEBER A. Slovnica hrvatska za srednja učilišta. Zagreb, 1876.

VEBER 1887 = VEBER A. Djela Adolfa Vebera, III. Zagreb, 1887.

VINCE 1986 = VINCE Z. Mirko Divković i Tomo Maretić - takmaci u objavljivanju hrvatskih školskih gramatika // Filologija, 1986. № 14. 411-417.

VINCE 2002 = VINCE Z. Putovima hrvatskoga književnog jezika. Zagreb, 2002. 